\title{
Modernism and the Spiritual in Russian Art \\ New Perspectives
}

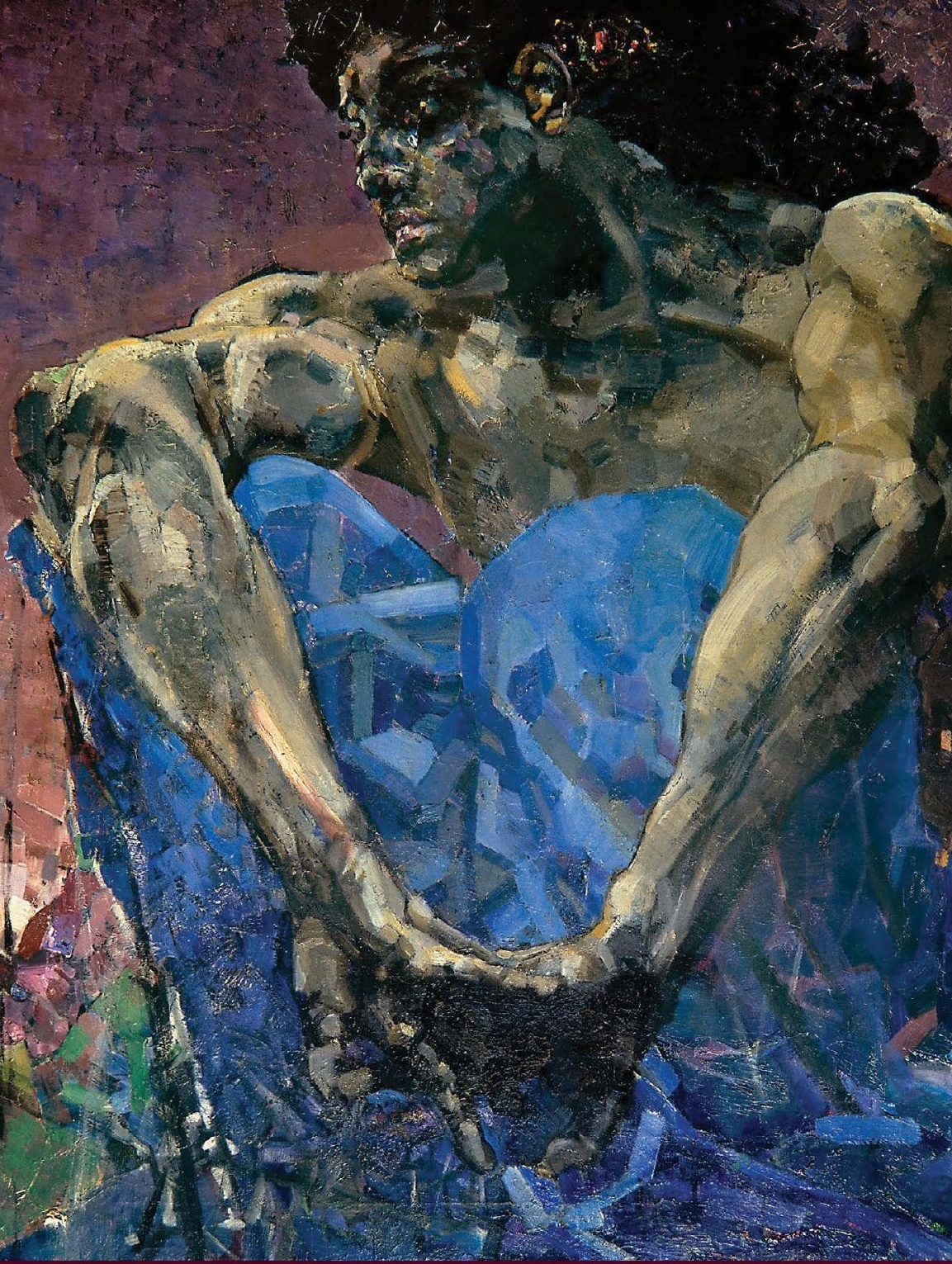

Edited by Louise Hardiman and Nicola Kozicharow 


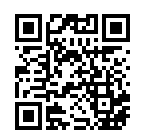

https://www.openbookpublishers.com

(C) 2017 Louise Hardiman and Nicola Kozicharow.

Copyright of each chapter is maintained by the author.

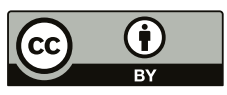

This work is licensed under a Creative Commons Attribution 4.0 International license (CC BY 4.0). This license allows you to share, copy, distribute and transmit the work; to adapt the work and to make commercial use of the work providing attribution is made to the authors (but not in any way that suggests that they endorse you or your use of the work). Attribution should include the following information:

Louise Hardiman and Nicola Kozicharow, Modernism and the Spiritual in Russian Art: New Perspectives. Cambridge, UK: Open Book Publishers, 2017, https://doi.org/10.11647/OBP.0115

In order to access detailed and updated information on the license, please visit https://www.openbookpublishers.com/product/609\#copyright

Further details about CC BY licenses are available at http://creativecommons.org/licenses/by/4.0/

All external links were active at the time of publication unless otherwise stated and have been archived via the Internet Archive Wayback Machine at https://archive.org/web

Digital material and resources associated with this volume are available at https://www.openbookpublishers.com/product/609\#resources

Every effort has been made to identify and contact copyright holders and any omission or error will be corrected if notification is made to the publisher.

The publication of this volume has been made possible by a grant from the Scouloudi Foundation in association with the Institute of Historical Research at the School of Advanced Study, University of London.

ISBN Paperback: 978-1-78374-338-4

ISBN Hardback: 978-1-78374-339-1

ISBN Digital (PDF): 978-1-78374-340-7

ISBN Digital ebook (epub): 978-1-78374-341-4

ISBN Digital ebook (mobi): 978-1-78374-342-1

DOI: $10.11647 / \mathrm{OBP} .0115$

Cover image: Mikhail Vrubel, Demon Seated (1890), detail, Wikimedia, https://upload.wikimedia.org/ wikipedia/commons/9/9f/Vrubel_Demon.jpg

Cover design: Heidi Coburn

All paper used by Open Book Publishers is sourced from SFI (Sustainable Forestry Initiative) accredited mills and the waste is disposed of in an environmentally friendly way. 


\title{
9. Stelletsky's Murals at Saint-Serge: Orthodoxy and the Neo-Russian Style in Emigration
}

\author{
Nicola Kozicharow
}

In 1911 the artist and critic Alexandre Benois wrote in an article on Dmitry Stelletsky in the journal Apollo (Apollon): "I want to see whole cathedrals painted by Stelletsky [...]. An authentic, ancient harmony would be revived, as would the miraculous exterior [and] aesthetic quality of ancient displays [...]. In such churches it would seem that Byzantium lived again and all authentic features of its art displayed." ${ }^{1}$ Almost two and a half decades later, Benois seemed to get his wish. Between 1925 and 1927, Stelletsky executed the murals and iconostasis for the parish church of the Saint-Serge Theological Institute in Paris - one of the most important centres of the Russian Orthodox Church after the Bolsheviks' repression of religion in the Soviet Union began in 1918. Benois's desires, however, were only partly fulfilled; Byzantium did not live again in these innovative designs. The highly stylised, colourful, sometimes even playful, mural scheme and its daring deviations from the Orthodox canon represented an unusual departure for Stelletsky both as an artist and a devout Orthodox believer. ${ }^{2}$ His secular paintings generally corresponded closely with medieval forms - so much so that the Russian avant-garde condemned his work as imitative - and his published edict on icon painting emphasised the importance of maintaining a strict adherence to Orthodox

1 Aleksandr Benua, 'Iskusstvo Stelletskago', Apollon, 4 (1911), 5-13 (p. 10), http://www.v-ivanov. it/issledovaniya_i_materialy/apollon “Мне бы хотелось видеть целые соборы, расписанные Стеллецким...Возродились бы подлинныя древния гармонии, возродилась бы вся чудесная внешняя, эстетическая, сторона древних действ...В таких храмах казалось-бы, что все еще жива Византия и подлинна вся показная сторона ея искусства."

2 For K. P. Semenov-Tian-Shanskii, the designs represent an "unyieldingly individual, creative search" (“упорного индивидуального, творческого поиска"). К. P. Semenov-Tian-Shanskii, 'Dmitrii Semenovich Stelletskii', Khorugv', 9 (2004), 3-39 (p. 26). 
iconography, yet in Paris his designs for this important religious commission were the most experimental of his career. ${ }^{3}$ This chapter considers how Stelletsky's radical use of religious space at Saint-Serge upheld enough of the canon to be viewed as authentic, yet, on the whole, appeared to reflect a more modernist approach that prioritised aesthetic, rather than religious concerns. It will also explore the possibility that his position outside of the avant-garde was less straightforward than his contemporaries and scholars have suggested, at least in the case of these designs.

Before emigration, Stelletsky became well known for his almost forensic dedication to the forms and subjects of Old Russian (drevnerusskii) art. ${ }^{4}$ Old Russian or medieval Russian culture had existed before the reign of Peter the Great, when the arts, which had previously been almost solely in the service of the Orthodox Church, were secularised and more western modes of representation were introduced. This meant that Old Russian art - especially religious objects such as icons - retained and further developed aesthetics passed down from Byzantium to Russia in the form of icon painting from the late tenth century onwards. Born into a devoutly Russian Orthodox, wealthy, noble family in Brest-Livotsk, Stelletsky was able to begin his studies at the Imperial Academy of Arts in St Petersburg in 1896, thanks to his parents' financial support. ${ }^{5}$ There, he quickly began to build up an extensive knowledge of Russian medieval art and architecture. He copied ancient monuments and studied Old Russian art in the Academy's library, and this interest soon drove him to travel on artistic expeditions with his friend and fellow student, Boris Kustodiev, visiting the village of Semenovskoe-Lapotnoe in Kostroma Province in 1900 and Novgorod in 1903. ${ }^{6}$ It is likely that Stelletsky acquired the necessary skills to become an icon painter during these visits, although the exact nature of this training or where it took place is unknown. In his painting, he used tempera in the manner of icon painters, and his subjects were almost solely taken from Old Russian life and history and, occasionally, allegories of the seasons or times of day. Compositions and motifs were often repeated from canvas to canvas, especially in emigration. Apart from portraits, subjects from contemporary life rarely appeared in his oeuvre.

Stelletsky was far from the only artist at this time to take an interest in the revival of Russian national culture. Princess Maria Tenisheva's artist colony at Talashkino was one of several settlements in the late nineteenth to early twentieth centuries that sought to re-establish peasant crafts that were disappearing after Russia's accelerated

3 For more on Stelletsky's career in emigration see: Nicola Kozicharow, 'Dmitrii Stelletskii and Filipp Maliavin in Emigration: Dreaming of Russia and Resisting Change' (unpublished PhD thesis, University of Cambridge, 2016).

4 Throughout the chapter, the term Old Russian or medieval will be used to describe art created before the reign of Peter the Great.

5 Semenov-Tian-Shanskii, 'Stelletskii', pp. 3-4.

6 Semenskoe-Lapotnoe became the subject of one of Kustodiev's paintings, earning him a gold medal at the Academy in 1903. 
period of industrialisation. ${ }^{7}$ Workshops run by professional artists instructed peasants in different arts, and Tenisheva requested Stelletsky's expertise for a paid position at Talashkino. Arriving in the summer of 1904, Stelletsky primarily made designs for the ceramics studio, but also worked in wood and embroidery. ${ }^{8}$ In 1904, along with other Talashkino artists, Stelletsky did another Russian architecture tour, this time to visit ancient cities including Rostov, Yaroslavl, Kirillov, and the Ferapontov Monastery. The wall paintings in the latter by the renowned fifteenth-century icon painter Dionisy were an important highlight and would influence his designs for Saint-Serge decades later.

The widespread artistic engagement with national forms in the late nineteenth to early twentieth century became known as the neo-Russian style. Artists interpreted and misinterpreted a wide array of national sources to construct a single category without localising specific influences; accuracy was not necessarily imperative. ${ }^{9}$ The work of Viktor Vasnetsov, who had collaborated with other artists on the Church of the Saviour Not Made by Hands at Abramtsevo (1881-82) - arguably the origin of the neo-Russian style in architecture - helped define this style and popularise it among artists like Stelletsky. ${ }^{10}$ In the case of his illustrations for the epic Song of Oleg the Wise, for example, Vasnetsov indiscriminately selected costumes from church murals and icons to create new art 'in the spirit' of older periods. ${ }^{11}$ Stelletsky shared this tendency to draw inspiration from a variety of Russian visual motifs. He blended elements of icon painting and illuminated manuscripts to create a highly idiosyncratic style. Even his icons retained a look that was uniquely his own. His attention to the original sources, however, was far more academic than most. Stelletsky once complained to Kustodiev that Tenisheva "does not pursue the Russian style but that of a 'fairy tale'", even if

7 For more on Talashkino, see Sergei Makovskii, Talashkino: izdeliia masterskikh kn. M. Kl. Tenishevoi (St Petersburg: Sodruzhestvo, 1905); M. K. Tenisheva, Vpechatleniia moei zhizni (Paris: Izd. Russkago istoriko-genealogicheskago ob-va vo Frantsii, 1933); Wendy R. Salmond, Arts and Crafts in Late Imperial Russia: Reviving the Kustar Art Industries, 1870-1917 (Cambridge: Cambridge University Press, 1996), pp. 115-43.

8 For Stelletsky's impressions of his work there, see Letter from Dmitry Stelletsky to Boris Kustodiev, undated, in Talashkino. Sbornik dokumentov, ed. by L. S. Zhuravleva (Smolensk: Posokh, 1995), p. 357. In some sources, Stelletsky has been recorded as being at Talashkino as early as late 1903, but I have not found evidence of this.

9 For more on the neo-Russian style, see Rosalind P. Blakesley, The Arts and Crafts Movement (London: Phaidon Press, 2009), pp. 159-75; Katia Dianina, When Art Makes News: Writing Culture and Identity in Imperial Russia, 1851-1900 (DeKalb, IL: Northern Illinois University Press, 2012), pp. 191-217. There is some confusion over this term as the neo-Russian style is often subsumed under the broader category of the Russian style (russkii stil'), which refers to the interest in Russian national culture in art and architecture from the mid-nineteenth century onwards. This chapter will use the term 'neo-Russian style' to refer to, as Evgenia Kirichenko defines it, a trend that emerged in the late nineteenth century, which largely originated at the Abramtsevo artist colony, and subsequently informed the work of Stelletsky and other artists such as Ivan Bilibin. Evgenia Kirichenko, Russian Design and the Fine Arts 1750-1917 (New York: Harry N. Abrams, 1991), pp. 134-41.

10 Inge Wierda, 'Abramtsevo's Neo-Medieval Church: A Manifestation of Sobornost', in Aesthetics as a Religious Factor in Eastern and Western Christianity, ed. by Wil van den Bercken and Jonathan Sutton, (Leuven: Peeters, 2005), p. 261.

11 Kirichenko, Russian Design, p. 150. 
some of his motifs at Saint-Serge echoed her work, particularly in embroideries. ${ }^{12}$ For Stelletsky, the neo-Russian style represented a serious attempt to know and engage with Old Russian art in a way that was faithful to the source for both spiritual and aesthetic reasons, as we will see with reference to Saint-Serge.

This did not mean that Stelletsky copied forms exactly from medieval sources. Total accuracy was, in fact, an impossibility that Stelletsky acknowledged: "How our ancestors dressed long ago, what drawings their dwellings were decked with, utensils, dresses - of these we know nothing." ${ }^{13}$ Despite the interpretative nature of his art, however, his contemporaries and foreigners alike often took his work too literally; Russians in emigration referred to Saint-Serge, for example, as a genuine "copy" of a sixteenth-century Russian church. There were critics who understood his approach. Sergei Makovsky, for example, clearly stated that:

Stelletskii does not aspire to accuracy; he borrows from Old Russia that which answers to the twelfth century in spirit, but he does not think at all about imitation of the pedantic image of some date, of some iconographic manner. He draws from the 'broad' old times, beloved and intimate, freely choosing that which is needed for an artistic whole, combining taste with unity $[\ldots]^{14}$

But, at the same time, Makovsky felt that Stelletsky "feels the drawing, colour, pattern, [and] descriptive allegory like a man of those times, like an ancient man, not knowing another language $[\ldots]^{\prime \prime} .{ }^{15}$ This spiritual connection to the past was also a key part of Stelletsky's art according to Benois, who referred to him as an "expert [...] on Russian style". ${ }^{16}$

The formal link between Stelletsky's art and that of pre-Petrine Russia helped to earn him a place at one of the first major displays of European modernism to be seen in Britain: the 'Second Post-Impressionist Exhibition' in London in 1912. At this exhibition, Stelletsky was positioned as a leading figure in contemporary art, and the apparent Russian equivalent of European avant-garde artists such as Pablo Picasso and Henri Matisse. The revival of interest in Byzantine art in Britain in the years leading up to the exhibition had led critics such as Roger Fry, T. E. Hulme, and Clive Bell to

12 Zhuravleva, Talashkino. Sbornik, p. 358. “проводит не русский стидь, а 'сказочный”'.

13 D. S. Stelletskii, 'Vvedenie', Russkiia narodnyia chastushki/risunki (Riga: Ernst Plates, 1937). “А как в те далекия времена одевались наши предки, какими рисунками были изукрашены их жилища, утварь, плате - мы ничего не знаем."

14 Sergei Makovsky, "'Slovo o polku Igoria” Stelletskago', Vremennik Obshchestva druzei russkoi knigi, 2 (1928), 11-18 (р. 13). “Стеллецкий не претендует на точность, он берет у древность все, что отвечает по духу двенадцатому веку, но думает вовсе о подделке книжнаго образца такой-то даты, такого-то иконографическаго пошиба. Он черпает их 'обширной' старины, воздюбленной и близкой, свободно выбирая то, что нужно для художественнаго целаго, связаннаго единством вкуса [...]."

15 Makovsky, “'Slovo o polku Igoria”', p. 12. “чувствует рисунок, краску, узор, начертательную аллегорию, как человек тех времен, как древний человек, не знающий иного языка[...]”.

16 Alexandre Benois, Reminiscences of the Russian Ballet, trans. by Mary Britnieva (London: Putnam, 1945), p. 306. 
identify a formal link between Byzantine and modernist art. ${ }^{17}$ The strength of this connection was such that when Boris Anrep came to organise a Russian section of Fry's Second Post-Impressionist Exhibition, Stelletsky, whose work could be closely related to Byzantine icon painting through his interest in Old Russian art, was an obvious choice. In the exhibition catalogue, Anrep even stated that Stelletsky was the leader of a "new Byzantine" group in Russia, which also included Nicholas Roerich and Anrep himself. ${ }^{18}$ Within the context of this exhibition, the close relationship between Stelletsky's work and that of Old Russia, which upheld and reworked Byzantine forms, made him a modernist, allying his art with current trends in France.

This association, however, was fleeting, and his work, though the most well received of the Russians, gained little recognition outside this exhibition. Within a Russian context, Stelletsky's intimacy with historic modes of representation even drew criticism from avant-garde artists in Russia. In his 1913 text on Neoprimitivism, Aleksandr Shevchenko described the way in which artists should use primitive forms: "This does not involve simple imitation [...] not what, for example, is being done by Stelletsky, whose works in no way reveal old Russia, Byzantium, or icons. They are mere historicity - a resolution of high ideas by home-made, amateurish means, an imitation devoid of reception."19 As Jane Sharp has discussed, Shevchenko believed the exactitude with which Stelletsky replicated the pictorial forms of icons meant that he suffered from an acute disengagement from the contemporary world. ${ }^{20}$ Grishchenko - a painter closely aligned with Shevchenko - echoed these sentiments in 1917, describing the way Stelletsky and others revived ancient art: "[...] we should most categorically condemn the attempts of Russian artists to reconstruct the ancient worldview in dead imitative forms" ${ }^{21}$ Goncharova, too, despised imitation: "We have not learned the most important thing: not to make stupid imitations and not to seek our individuality but to create, in the main, works of art." 22 The idea that Stelletsky painted through the "eyes of the ancients", which was so lauded by Makovsky and Benois, was anathema for Shevchenko, and made his work the antithesis of Neoprimitivism.

17 J. B. Bullen, 'Byzantinism and Modernism 1900-14', The Burlington Magazine, 141, 1160 (November 1999), 665-75; J. B. Bullen, 'Byzantinism and British Modernism', in Continental Crosscurrents. British Criticism and European Art 1810-1910, ed. by J. B. Bullen (Oxford: Oxford University Press, 2005), pp. 225-47. See also Byzantium/Modernism (Visualising the Middle Ages), ed. by Roland Betancourt and Maria Taroutina (Leiden: Brill, 2015).

18 Boris von Anrep, 'The Russian Group', in Second Post-Impressionist Exhibition Catalogue (exh. cat., Grafton Galleries, London, 1912), pp. 30-33 (p. 31).

19 Aleksandr Shevchenko, 'Neoprimitivism: Its Theory, Its Potentials, Its Achievements', in Russian Art of the Avant-Garde: Theory and Criticism 1902-1934, ed. by John E. Bowlt (London: Thames \& Hudson, 1988), p. 48.

20 Sharp, Russian Modernism between East and West, p. 250.

21 A. Grishchenko, Voprosy zhivopisi. Vypusk 3-i. Russkaia ikona kak iskusstvo zhivopisi (Moscow: Izdanie avtora, 1917), p. 263. “мы должны самым категорическим образом осудить попытки русских художников реконструировать древнее мировоззрение в мертвых, подделочных формах".

22 Natalia Goncharova, 'Preface to Catalogue of One-Man Exhibition', in Russian Art of the Avant-Garde: Theory and Criticism 1902-1934, ed. by John E. Bowlt (New York: Viking Press, 1976), pp. 54-60 (p. 57). 
For Stelletsky, however, imitation could potentially play an important role in the understanding of Old Russian art. He wrote in his memoirs: "It befits the Russian people to have their own art. Over the years, I understood that only by learning the artistic legacy of our ancestors and even, at the beginning, slavishly imitating it, it is possible...to resurrect our own Russian, native beauty." ${ }^{23}$ When it came to religious painting, Stelletsky's opinion was similar. In an article he contributed to the Rigabased journal Native Antiquity (Rodnaia starina) in 1928 - a year after he completed his work at Saint-Serge - he wrote of the importance of following the canon when painting icons: “One of the Old Russian system's main responsibilities was, as we know, the precise observation of the canon, which embraced all sides of spiritual and everyday life. The canon of icon painting demanded its painters' stringent observation of the established style." ${ }^{24}$ These restrictions appeared to place "shackles" (okovy) on artistic creativity, but were essential in continuing the tradition. ${ }^{25}$ Although he did not discuss his own icon painting, it is clear from the article that preserving the tradition, as handed down through hundreds of years of history, was key for Stelletsky. ${ }^{26}$

This dedication most likely stemmed, at least in part, from Stelletsky's firm Orthodox faith. His convictions were so strong that he had rejected Diaghilev's invitation to design for his ballet of the life of Christ - Liturgie - in 1915 on religious and moral grounds. ${ }^{27}$ Deeply religious and, as prominent émigré critic Mikhail Osorgin put it,

23 Quoted in Oleg Leikind and Dmitrii Severiukhin, Khudozhniki russkoi emigratsii, 1917-1941: biograficheskii slovar' (St Petersburg: Izd-vo Chernysheva, 1994), p. 431. "Русскому народу подобает иметь свое искусство. С годами я понял, что, тодько изучая художественное наследие наших предков и даже сначала рабски ему подражая, можно [...] воскресить свою русскую родную красоту."

24 Dmitrii Stelletskii, 'Dragotsennaia tsep", Rodnaia starina, 5.6 (1928), 21-22 (р. 22). “Одною из главных обязанностей древне-русскаго строя было, как известно, точное соблюдение канона, обнимавшаго все стороны духовной и обыденной жизни. Канон иконописи требовал от изографов строжайшаго соблюдения установленнаго типа." Ibid.

26 Stelletsky was up to date with the latest scholarship on icon painting and responded enthusiastically to Aleksandr Animisov's study of the recently cleaned Vladimir Mother of God in a letter to Princess Natalia Iashvil, who helped translate the book into English (Letters from Stelletsky to Princess Natalia Iashvil, 2 and 20 March 1928 (KI 41), Kondakov Institute.) Animisov revealed that the oldest layer of paint dated back to the eleventh to twelfth centuries, making the Vladimir Mother of God much older than previously speculated by Nikodim Kondakov. The book reproduced images of the icon along with a diagram of the layers of repair and restoration (A. J. Animisov, Our Lady of Vladimir, trans. by N. G. Yaschwill and T. N. Rodzianko (Prague: Seminarium Kondakovianum, 1928)). For more information on Animisov's text and the effort to get it published, see Shirley A. Glade, 'Anisimov and the Rediscovery of Old Russian Icons', in Alter Icons: The Russian Icon and Modernity, ed. by Jefferson J. A. Gatrall and Douglas Greenfield (University Park: Pennsylvania State University Press, 2010), pp. 89-111.

27 See Vera Bunina's diary entry on 16 August 1930 in Ivan Bunin and Vera Muromtseva-Bunina, Ustami Buninykh. Dnevniki Ivana Alekseevicha $i$ Very Nikolaevny $i$ drugie arkhivnye materialy, ed. by Militsa Grin, Vol. 2 (Frankfurt: Posev, 1982), p. 230. See also John E. Bowlt, 'Léon Bakst, Natalia Goncharova and Pablo Picasso', Diaghilev and the Golden Age of the Ballets Russes, 1909-1929, ed. by Jane Pritchard and Geoffrey Marsh (London: V\&A Publications, 2010), pp. 103-17 (p. 108). It was Stelletsky who suggested that Diaghilev ask Goncharova to carry out the designs, and Stelletsky later wrote to Goncharova, asking for her help in getting in touch with Diaghilev. Letters from Stelletsky to Goncharova, 30 June 1917, 13 July 1917 (f. 180, ed. khr. 1714-15), Tretyakov Gallery. This dialogue 
"Russian Orthodox to the bone". ${ }^{28}$ Stelletsky called his work at Saint-Serge "a service to God". ${ }^{29}$ Indeed he took on this two-year commission only at the cost of room and board at time when money and work were hard to come by, suggesting this work was more important than material concerns. ${ }^{30}$

Yet in practice, while visual continuity with Old Russian churches in Russia was a central concern, Stelletsky more loosely interprets older modes of representation in many of his church designs. This freer, more experimental approach to medieval revivalism was in keeping with the neo-Russian style, especially the neo-Russian tendencies incorporated within the modern Russian architectural style popular at the turn of the century: style moderne. ${ }^{31}$ In what William Brumfield has described as "a remarkable confluence of purpose and understanding", contemporaries of Stelletsky such as Sergei Maliutin and Roerich - who were both at Talashkino - worked with style moderne architects to decorate interiors of churches and private buildings. ${ }^{32}$ This collaborative effort helped recreate "the logical bond between material and structure in the Old Russian or folk traditions of pre-Petrine Russian architecture" but generally emphasised theatricality and drama over imitation. ${ }^{33}$ Stelletsky is not associated with this group of neo-Russian practitioners (which also included, among others, Konstantin Korovin, Mikhail Vrubel, and the Vasnetsov brothers), yet given his virtually unacknowledged church commissions in Russia and work at SaintSerge in emigration, he undoubtedly engaged with the more modern strand of the neo-Russian style. He collaborated with Aleksei Shchusev, who was one of the most prominent proponents of style moderne in Russian church architecture, on several occasions. According to Brumfield, no one but Shchusev "understood better the harmony between medieval forms and the new aesthetic", for he was a follower of the tradition begun at Abramtsevo that - in words that could be applied to Stelletsky's work as well - "grasp[ed] and sens[ed] the sincerity of ancient times and creatively imitate[ed] it not in the copying out and correcting - that is, distorting - of old forms

suggests that even if the two artists had seemingly oppositional approaches, this did not rule out friendly relations and mutual respect between them.

28 Mikhail Osorgin, 'Pamiati D. S. Stelletskago', Tserkovnyi vestnik Zapadno-Evropeiskoi eparkhii, 6 (1947), 9-12 (р. 10). “до мозга костей русским православным человеком”.

29 Aleksandr Semenov-Tian'shanskii, 'Pamiati D. S. Stelletskogo', in Obshchestvo "Ikona" v Parizhe, ed. by G. I. Vzdornov, Z. E. Zalesskaia, and O. V. Lelekova (Moscow: Progress traditsiia, 2002), pp. 152-58 (p. 156). "служба Богу".

30 Donald A. Lowrie, Saint Sergius in Paris: The Orthodox Theological Institute (London: S. P. C. K., 1954), p. 13.

31 For more on style moderne or the 'new style' in architecture see William Craft Brumfield, The Origins of Modernism in Russian Architecture (Berkeley, CA: University of California Press, 1991); William Craft Brumfield, A History of Russian Architecture (Seattle: University of Washington Press, 2004), pp. 426-37.

32 Brumfield, The Origins of Modernism, p. 80. Stelletsky met Roerich at Talashkino and found much in common with him, writing to Kustodiev, 'I really agree with [Roerich] - I speak to him a lot about different questions.' Letter from Stelletsky to Kustodiev, undated, quoted in Zhuravleva, Talashkino. Sbornik, p. 357. 
but in the creation of new forms that express... the idea of a place of communion between the people and God". ${ }^{34}$

Shchusev's first church project - the Saint Sergius of Radonezh church in Tula province commemorating the Battle of Kulikovo - was in fact carried out with the assistance of Stelletsky and another artist, Vladimir Komarovsky, who both painted the icons. ${ }^{35}$ Count Iury Olsufev, a patron and close friend of Stelletsky, requested both artists' services for the church, and the work was executed sometime between 1911 and $1914 .{ }^{36}$ It is clear that Old Russian icons served as important source material for this commission: in a letter to Tretyakov Gallery director Ilia Ostroukhov from 1913, Stelletsky requested the return of his Saint Nicholas icon to create the iconostasis for Saint Sergius of Radonezh at Kulikovo fields. ${ }^{37}$ However, the only design by Stelletsky known to have survived (after the Revolution, the church was ransacked and badly damaged during the Bolshevik iconoclasm) is a sketch of Christ on the cross that is hardly canonical. ${ }^{38}$ The image relates closely to his secular work in the stylised treatment of form and diverts from tradition in the unusual blue colouring of Christ's skin. It would appear, at least in the case of this design, Stelletsky shared Shchusev's willingness to deviate from convention in design but preserve the spirit of medieval Russia.

Over a decade later, Stelletsky received the most significant commission of his career when he was tasked with decorating the entire interior of Saint-Serge - arguably the most important centre of the Orthodox faith outside of Russia - based on his own designs. Although he had developed a reputation for copying Old Russian artistic precursors very closely, Stelletsky nonetheless stepped outside of the canon for the church's vibrant wall scheme. Rather than superimposing a medieval rubric

$34 \quad$ Ibid., p. 104.

35 Ibid.

36 Kari Kotkavaara, Progeny of the Icon: Émigré Revivalism and the Vicissitudes of the Eastern Orthodox Sacred Image (Åbo: Åbo Akademi, 1999), p. 183.

37 Letter from Dmitry Stelletsky to Ilia Ostroukhov, 2 August 1913 (f. 10, ed. khr. 6037), Tretyakov Gallery.

38 For an illustration, see E. V. Tarasenko, Dary i priobreteniia: novye postupleniia $v$ sobranii grafiki XVIIInachala XX veka. Risunok, pechatnaia grafika. Katalog vystavki (exh. cat., Tretyakov Gallery, Moscow, 2013). Stelletsky also decorated a second church before emigrating in 1914. As Galina Zelenskaia has established, it was commissioned by Count Aleksandr Medem in 1911 for his estate Aleksandriia near Khvalynski on the Volga and dedicated to Saints Constantine and Helene. The iconostasis was lost after the Revolution, so it is difficult to know what form Stelletsky's icons took before emigration, but the fact that he executed some church painting before Saint-Serge is significant. Cited in Kotkavaara, Progeny, pp. 182-83. During the First World War, Stelletsky executed several travelling iconostases for Russian soldiers stationed in Champagne, and one of these survived and was held in the private collection of Nikolai Semenov-Tian'shansky - brother to Aleksandr. Stelletsky reworked it in 1939-40 when it was installed at the Church of Saints Peter and Paul in Châtenay-Malabry. For more information, see T. V. Iur'eva, 'Ikonostasy D. S. Stelletskogo', in X nauchnye chteniia pamiati Iriny Petrovny Bolottsevoi: Sbornik statei, ed. by O. B. Kuznetsova and E. Iu. Makarova (Yaroslavl: Avers Press, 2006), pp. 144-60, http://www.icon-art.info/book_contents.php?book_id=60. For a reproduction, see Semenov-Tian-Shanskii, 'Stelletskii', pp. 34-35. 
onto Saint-Serge, Stelletsky's designs were far closer to the neo-Russian style's free interpretation of Old Russian forms and folk motifs, particularly within style moderne. Yet he still maintained enough of a visual connection to earlier Russian churches - primarily through the hanging cloth motifs running along the lower areas of the walls of the church - for the building to be convincing as an Orthodox church.

Stelletsky's experimentation may have partly been out of necessity, given the church building was not Orthodox, but nineteenth-century gothic. Unlike an Orthodox cross-in-square church plan, as seen, for example, at the Church of the Nativity of the Virgin at the Ferapontov Monastery, Saint-Serge follows a standard cruciform plan, thus presenting Stelletsky with a challenge: how does an artist develop an Orthodox programme in this structure? Instead of limiting his use of the church's space, incorporating the foreign structural elements such as the rose windows and the barrelvaulted nave into the scheme ended up inspiring some of the more inventive designs at Saint-Serge. This creative flexibility emphasises that Stelletsky, though attentive to Orthodox Church requirements, used the most public commission of his career to assert his own style and boldly experiment on a large scale.

Through Stelletsky's murals, Saint-Serge became not a 'copy' of an Old Russian church, as some of his contemporaries viewed it, but a new exemplar of the neo-Russian style in emigration. ${ }^{39}$ Like other artists and architects working in this style, Stelletsky drew from and reinterpreted an array of Old Russian sources such as embroidery, manuscripts, and icons, and took more recent developments in artist colonies such as Abramtsevo into account. The widespread revival of Old Russian culture that reached its peak in early twentieth-century Russian art and architecture had been cut short by the Revolution, thus Stelletsky's designs at Saint-Serge helped perpetuate this interest in emigration. ${ }^{40}$

Stelletsky's approach to the neo-Russian style is clearly expressed through the most unusual element of his wall painting: the predominance of colourful, stylised foliage throughout the interior (fig. 9.1). The use of these forms can be related to several different sources that the artist would have known. In terms of possible architectural precursors, the Tsarina's Golden Chamber (sixteenth century) and the Terem Palace at the Kremlin, which Stelletsky would at least have known through photographs and possibly pattern books, feature colourful ornamental designs that encompass

39 See, for example Lollii L'vov, 'Russkoe iskusstvo za granitsei', Illiustrirovannaia Rossiia, 17 (23 April 1927), 12-13 (p. 12); Iulia Reitlinger, quoted in Kotkavaara, Progeny, p. 259.

40 Marc Raeff has discussed the continued interest in medieval Russian culture abroad through, for example, the study of Slavic linguistics at the Cercle linguistique de Prague. The Bolsheviks had generally frowned upon medieval revival as it was closely connected with religious culture. Marc Raeff, Russia Abroad: A Cultural History of the Russian Emigration, 1919-1940 (New York and Oxford: Oxford University Press, 1990), pp. 99-100. 
large sections of the wall and ceilings. ${ }^{41}$ Both the Tsarina's Golden Chamber and Saint-Serge have decorative patterns running along the inside of the vaults, and the colour scheme of red and yellow is reminiscent of Stelletsky's in the gallery (fig. 9.2). The walls and ceilings of the Terem Palace, which were, due to fire, repainted in the revivalist style of the second quarter of the nineteenth century, are similarly covered in extensive ornamental designs. ${ }^{42}$ Many Orthodox churches also used such motifs in their interiors, notable examples including the Cathedral of Saint Vasily the Blessed (Saint Basil's) (1555-60) in Moscow and Saint Sophia Cathedral in Kyiv. ${ }^{43}$ A section of the wall design in the narthex can be connected with ornaments found in midseventeenth-century Yaroslavl churches, which Stelletsky visited in 1904, especially those at Saint Nicholas on the Stumps (1689-90). ${ }^{44}$

While the use of ornament at Saint-Serge was certainly inspired by the interiors of sixteenth- to seventeenth-century religious and secular buildings, the neo-Russian style would appear to have been of equal influence. Vasnetsov's set design for the Snow Maiden palace interior (c. 1885, Tretyakov Gallery, Moscow) may have played a role, especially the stylised, colourful floral motifs covering the walls. ${ }^{45}$ Artists practising the neo-Russian style within style moderne architecture, too, similarly filled the entire wallspace with designs. Roerich, for example, along with the architect Shchusev, carried out wall paintings and mosaics for the Trinity Cathedral at the Pochaev Monastery in the Ukraine (1905-12), which enveloped the walls in religious scenes and flower motifs. ${ }^{46}$ In his work for the apartment of N. P. Pertsov (1905-07) in Moscow, Maliutin adapted the teremok style popularised at Talashkino to a small interior with "dramatic" but "impractical" and "affected" results. ${ }^{47}$ Indeed, the interior is swarming with various decorative schemes of odd creatures and wild flowers competing for space, whereas Stelletsky chooses fewer elements, instead allowing rich colours to take centre stage in a much simpler, ordered interior. This application of bold colours is similar to the red and green chapel in Pavel Riabushinsky's manor-house in Moscow (1900), designed by the most prominent architect of style moderne, Fedor Shekhtel. Yet even Shekhtel's colours seem more subdued by comparison with Stelletsky's, in which vibrant green, red, yellow, and black are sharply contrasted.

41 The Tsarina's Golden Chamber has been repainted several times in its history, but the decorative scheme remains intact and has been largely well preserved. Kathleen Berton, Moscow: an Architectural History (London: Studio Visa, 1977) p. 78.

42 The original seventeenth-century interior of the Terem Palace has not survived but was repainted in the nineteenth-century revivalist style, which sought to use decorative motifs of the seventeenth century, reinterpreting these designs. See William Craft Brumfield, Gold in Azure: One Thousand Years of Russian Architecture (Boston: D. R. Godine, 1983), p. 223.

43 Although Saint Sophia was rebuilt in the seventeenth century after it was destroyed by the Mongols in 1239-40, the eleventh-century frescoes and tenth- to twelfth-century mosaics are, for the most part, well preserved. Brumfield, Gold in Azure, p. 23.

44 Lev Zander, 'V obiteli prepodobnago Sergiia', Pravoslavnaia mysl', 2 (1930), 188-99 (p. 191).

45 Dianina, When Art Makes News, p. 191.

46 Brumfield, The Origins of Modernism, p. 105.

47 Ibid., pp. 77, 83. 

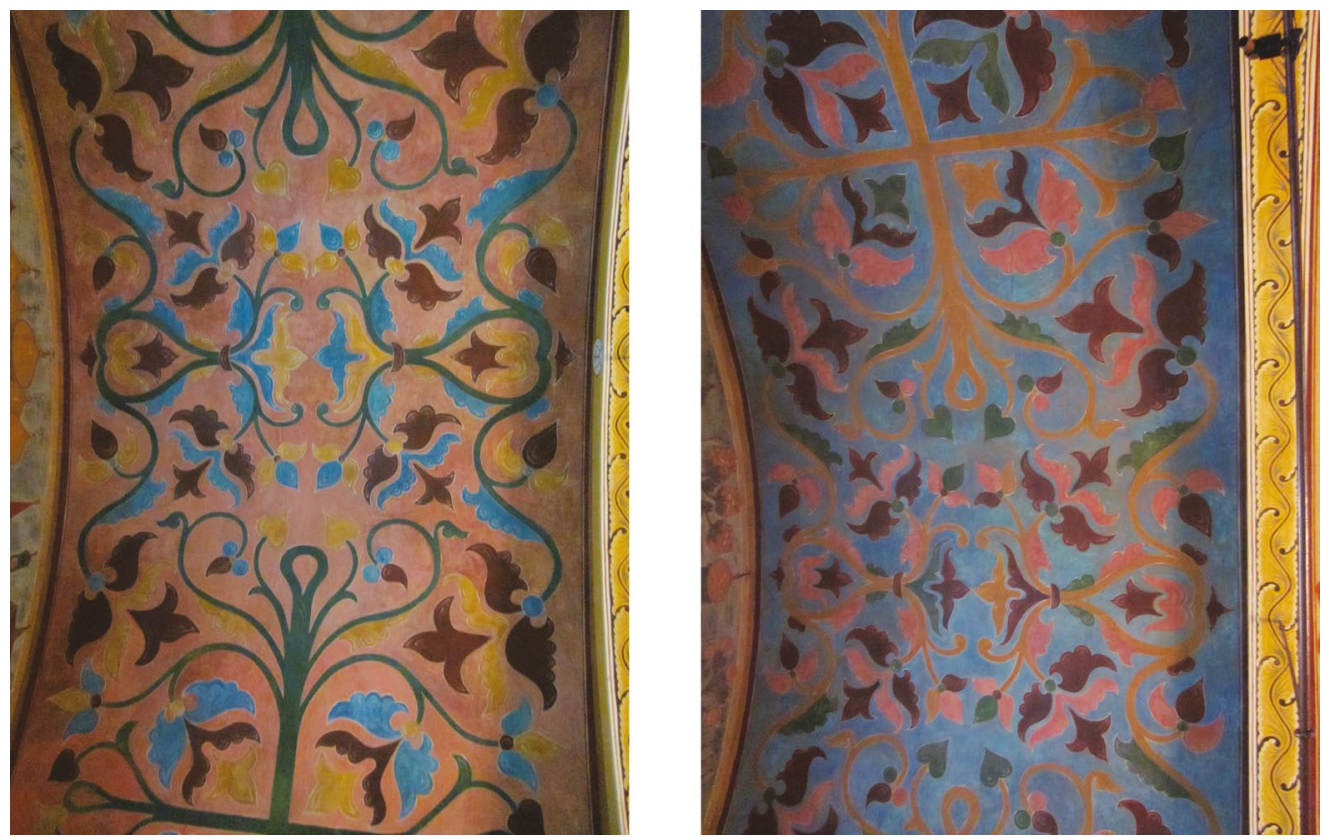

9.1a and 9.1b Dmitry Stelletsky, north and south transept vaults, 1925-27. Paris: SaintSerge Parish Church. Photograph (C) Nicola Kozicharow, CC BY 4.0.

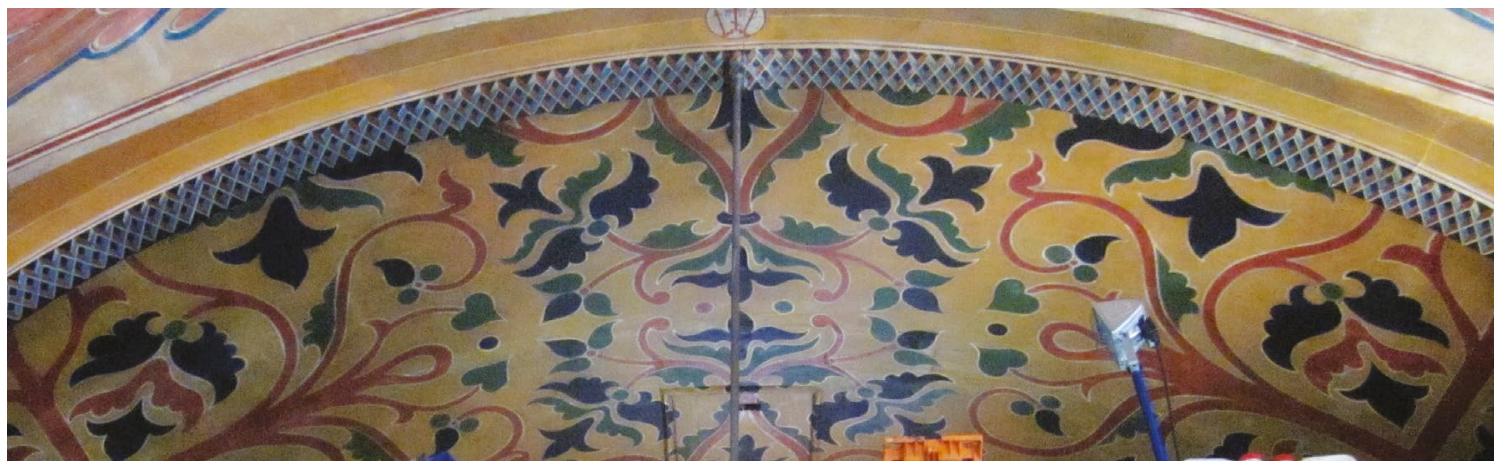

9.2 Dmitry Stelletsky, gallery arch, 1925-27. Saint-Serge, Paris. Photograph (C) Nicola Kozicharow, CC BY 4.0. 
The patterns and shapes of the ornaments themselves at Saint-Serge are more comparable with motifs found in medieval manuscripts and embroideries. Stelletsky was familiar with such influences through his own research and possibly also the Exhibition of Old Russian Art, which took place in Moscow in 1913. Designs from this exhibition do seem to correspond with many of Stelletsky's: the ornament on the wall to the right of the inside doors at Saint-Serge is reminiscent of the border at the bottom of a page from a manuscript of the Four Evangelists (1593-95), and a sixteenthcentury Apostolic Conversations manuscript has an undulating plant design close to that found in the north and south transept vaults. ${ }^{48}$ Embroideries, too, may have had an impact on Stelletsky, such as a pattern from a phelonion from the seventeenth century - also from the exhibition - with small, spade-shaped flowers. As with architectural designs, Stelletsky generally drew upon sixteenth-century forms from various media to create his ornamental motifs.

Not all of Stelletsky's sources for ornaments were, however, necessarily even Russian. In recently discovered sketchbooks of Stelletsky's, several drawings of ornaments at the French medieval cathedrals of Chartres and Rouen, dated March 1927, indicate he was influenced by western sources for Saint-Serge as well. ${ }^{49}$ This revelation reiterates the fact that Saint-Serge was far from the model of a Russian Orthodox church, but instead it represented Stelletsky's creative experimentation with his lexicon of Old Russian forms and knowledge of religious precedents, even un-Orthodox ones. It also suggests that empirical research was important to Stelletsky: in the absence of Old Russian churches in emigration, the observation of French ones would have to do.

Some sources were potentially more contemporary. The foliage on the wooden candle stand at Saint-Serge resembles the partitions in the Church of the Saviour Not Made by Hands at Abramtsevo (1881-82), which were most likely executed by Vasnetsov, who carved some of the floral motifs in the interior. ${ }^{50}$ Stelletsky may have visited Abramtsevo, or at least known of the church through photographs. His brief time at Talashkino, too, may have had an effect. It is possible to link the stylised, plant-like ornaments on the vestibule ceiling in the narthex with some of the designs created at Talashkino, such as, for example, cushions by Tenisheva. Stelletsky, though sympathetic to the aims of Talashkino, had, for the most part, little interest in the aspects of folk design that captivated his contemporaries such as the lubok and kustar crafts, and medieval book illumination remained his chief source of inspiration. This difference in national source material gave his designs a more refined appearance than those of Maliutin's, for example.

48 Vystavka drevnerusskogo iskusstva ustroennaia v 1913 godu v oznamenovanie chestvovaniia 300-letiia tsarstvovaniia Doma Romanovykh (Moscow: Imperatorskii Moskovskii Arkheologicheskii Institut Imeni Imperatora Nikolaia II, 1913), nos. 45 and 23.

49 There were four sketchbooks in total, which were in Stelletsky's possession when he died in 1947. Christie's London, Important Russian Art (catalogue, 24 November 2014), lot 7.

50 Eleonora Paston, Abramtsevo: iskusstvo i zhizn' (Moscow: Iskusstvo, 2003), p. 359. 


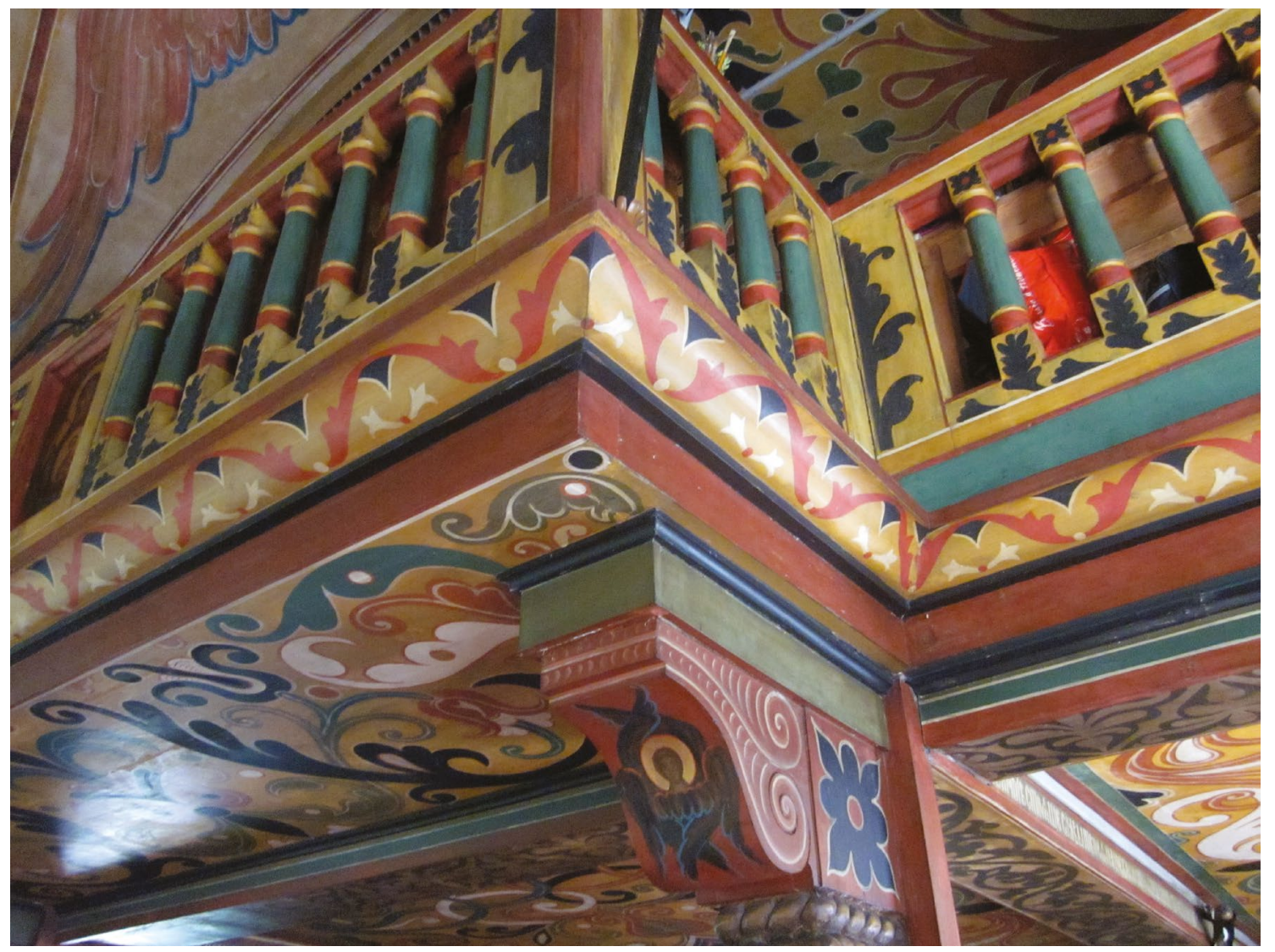

9.3 Dmitry Stelletsky, gallery balustrade, 1925-27. Saint-Serge Parish Church, Paris. Photograph (c) Nicola Kozicharow, CC BY 4.0. 
The stylisation of some of Stelletsky's designs, particularly on the balustrade of the gallery (fig. 9.3), even go beyond reference to Old Russian or national precedents and appear closer to the formal interests of modernist artists. The black leaves, which are simply stylised with a single blue line, are sharply juxtaposed against the bold golden yellow and playfully dance along the balustrade. This sense of play through shape, emphasis of colour contrasts through light and dark hues, and overall flatness of the ornaments through lack of modelling have a strong correlation to Matisse's interiors from 1908 onwards. In addition, the rhythmic curve of motifs on along the gallery and in the archways, as well as the juxtaposition of strong colours, resemble Matisse's ornamental arabesques in paintings such as The Dessert: Harmony in Red (State Hermitage Museum, St Petersburg, 1908), which Stelletsky may have known from the collection of Sergei Shchukin in Moscow. Stelletsky's use of colour in the interior - and even, to an extent, in the bold greens, reds, and blues, in the iconostasis - also represents "a reduction of essentials", as Jack Flam put it with regard to Matisse's own use of colour. ${ }^{51}$ This formal connection with Matisse underlines the fact that Stelletsky may not have been labelled a modernist by the avant-garde, but his association with the 'Second Post-Impressionist Exhibition' was perhaps more justified than previously thought. The expressive power of colour, although here used to spiritual effect, was of clear importance to Stelletsky. While he may have drawn inspiration from the use of bold colours such as red in Novgorod icons - as did, in fact, Matisse on his visit to Moscow in 1911 - the explosion of bright colour at Saint-Serge was not wedded to bygone sources, but rather showed the free play of imagination. ${ }^{52}$

Moreover, Stelletsky's marked, extensive use of these colourful motifs is virtually unprecedented in Orthodox Church architecture. Instead of mere decorative patterns, these ornaments play a dominant role in the overall design, filling the entire space of the narthex, gallery, and the large arches over the north and south transepts (fig. 9.4). ${ }^{53}$ There is a spiritual significance to these forms, which Lev Zander, a professor at the Institute, described as "holy flowers and herbs" ${ }^{54}$ Indeed the nonfigurative murals may have been a deliberate way to draw the worshippers' attention to the sacred images on the iconostasis. As much as Stelletsky was interested in Old Russian predecessors in church design, the customary figurative mural schemes typically found in such churches did not have a central place in Stelletsky's design. Even with comparison to Roerich's neo-Russian style wall paintings for the Trinity Cathedral, religious scenes and figures play a dominant role, and floral motifs are restricted to

51 Jack Flam, Matisse on Art (Berkeley, CA: University of California Press, 1995), p. 36.

52 Iu. A. Rusakov, 'Matisse in Russia in the Autumn of 1911', trans. by John E. Bowlt, The Burlington Magazine, 117 (May 1975), 284-91, and Alison Hilton, 'Matisse in Moscow', Art Journal, 29 (Winter 1969-70), 166-74, https://doi.org/10.2307/775225

53 It should be noted that Stelletsky installed the gallery himself, according to Kotkavaara, Progeny, p. 254.

54 “райскими цветами и травами”. Zander, 'V obiteli prepodobnago Sergiia', p. 131. 
archways and lower walls. Stelletsky's more inventive use of space thus reflected a fresh, more modern approach to the way in which areas of the church were painted both in traditional Orthodox churches and the neo-Russian style.

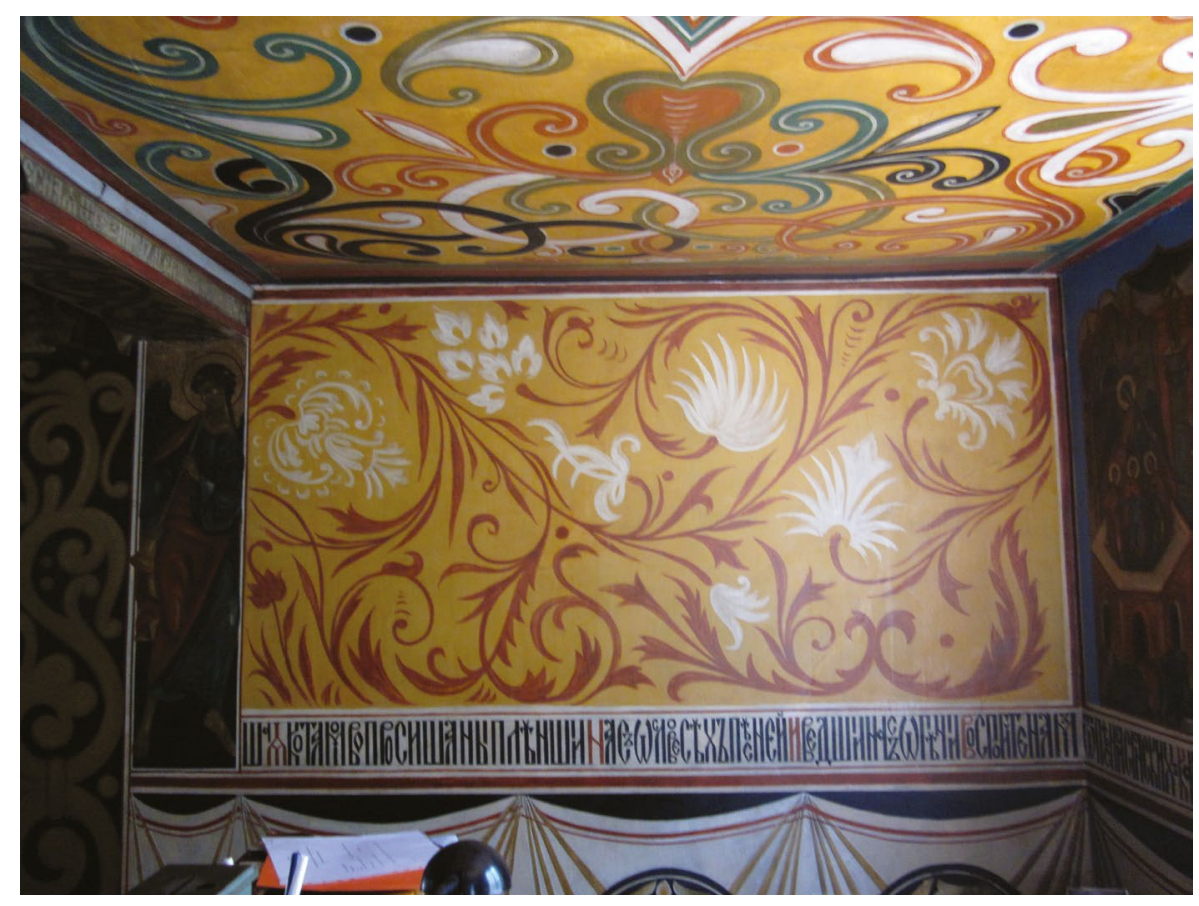

9.4 Dmitry Stelletsky, narthex, 1925-27. Saint-Serge, Paris. Photograph (C) Nicola Kozicharow, CC BY 4.0.

Stelletsky does not avoid figuration altogether: warrior saints and fathers of the church reside on the pillars supporting the vaults at the crossing in accordance with the tradition in Orthodox churches (and indeed, in Roerich's church)..$^{55} \mathrm{~A}$ few scenes such as Noah's ark adorn the walls of the narthex, and painted saints on board, though few, line the walls of the nave. Stelletsky therefore does not completely deviate from tradition in these spaces, especially in decorating the bottom half of the walls with hanging cloth motifs, which echo those at bastions of Orthodox medieval architecture such as the Church of the Nativity at Ferapontov Monastery. Rather, it is through Stelletsky's incorporation of the non-Orthodox gothic architecture that he stepped further outside the canon.

55 I would like to thank Richard Marks for first assisting me with identifying the iconography of Saint-Serge. 


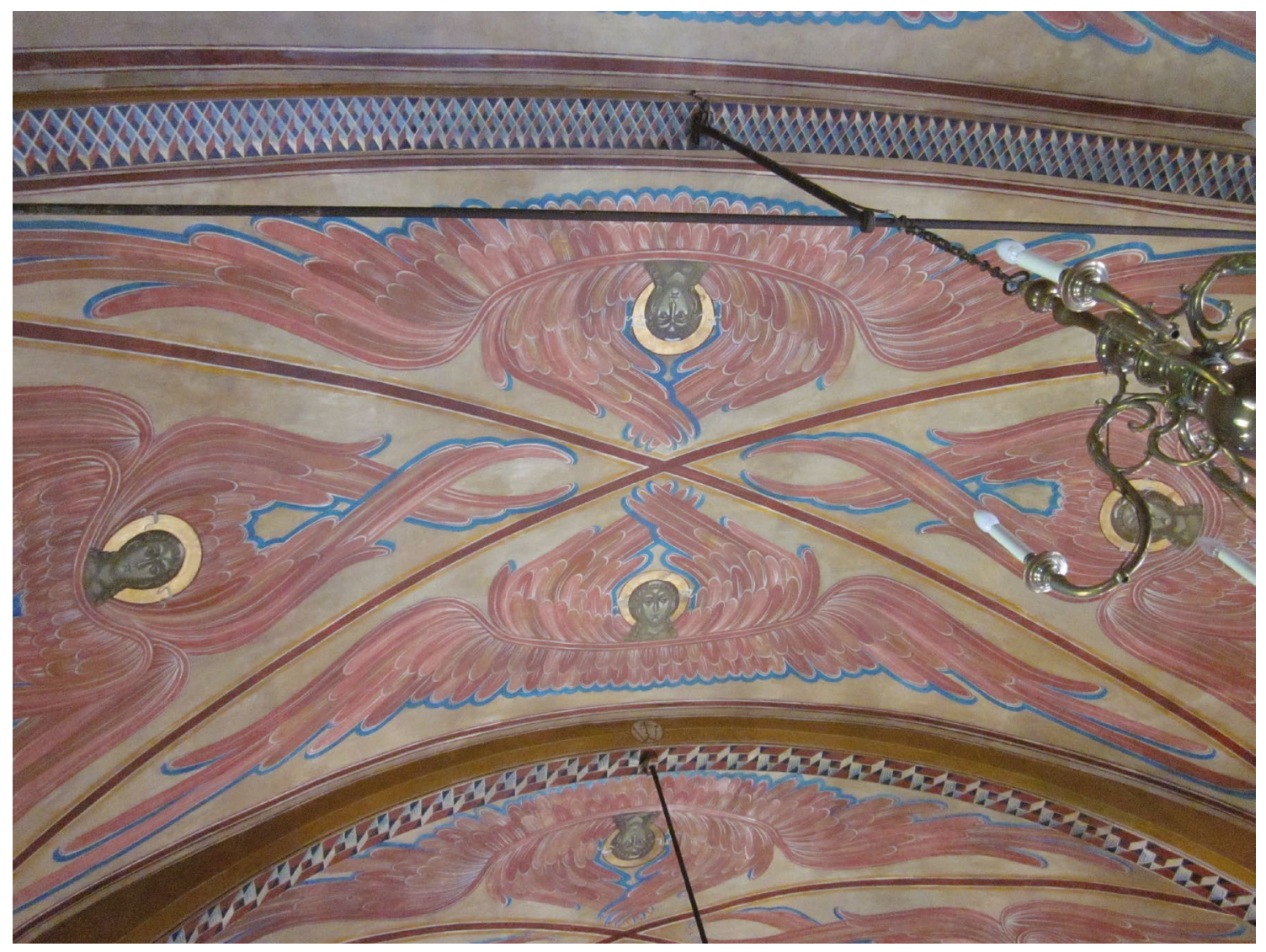

9.5 Dmitry Stelletsky, Seraphim, nave ceiling, 1925-27. Saint-Serge, Paris.

Photograph @ Nicola Kozicharow, CC BY 4.0. 
The way he integrated the long barrel-vaulted nave - an element not found in traditional Orthodox churches - perhaps jars the most with traditional Orthodox architecture and reflects the theatricality of the neo-Russian style. In each of the three vaults, he painted four seraphim. ${ }^{56}$ Literally meaning "burning ones", they are angels who circle the throne of God and are ordinarily found in icon painting (fig. 9.5). The centrality given to seraphim is exceptional: they do appear in wall painting, as in the Church of the Nativity on the walls of the nave and keystones of the arches, and on wooden church ceilings in Northern Russia, but tend to complement more important scenes and figures rather than take up a large amount of space. ${ }^{57}$ In Roerich's Trinity Cathedral, one large seraph appears on the walls as well. The seraph itself is a figure closely connected with Russian symbolism, and the subject of well-known painting by Vrubel (1904, State Russian Museum, St Petersburg). It is possible that Stelletsky was drawn to this theme through Vrubel, reflecting the dual influence of medieval and contemporary sources.

The seraphim's placement does loosely fit within the Orthodox canon. The ceiling of the nave constitutes one of the highest zones of Saint-Serge, where angels may be painted, and seraphim are the holiest beings in the Christian angelic hierarchy. In the iconography of the Virgin of the Sign, when the Virgin raises her hands to the heavens, seraphim or cherubim often circle above. ${ }^{58}$ In this icon, as Alfredo Tradigo points out, "her fingers open in prayer like two wings, echoed here by those of the cherubim", thus the holy gesture is repeated in the form of the angels. ${ }^{59}$ This iconography may have influenced Stelletsky's mural scheme, as the seraphim lead across the ceiling of the nave to the apse, where the Virgin of the Sign raises her arms towards them. This would certainly account for the unusual and extensive usage of the angels in such a holy area of the church. ${ }^{60}$ The repetition of the seraphim in the vaults also forms a pattern, which leads into the central crossing, where the four evangelists are painted in their animal forms. The evangelists are often part of the dome in the Orthodox canon - or on the ceiling in, for example, Rublev's wall paintings at Vladimir Cathedral - and Stelletsky placed them in front of the iconostasis, where a dome would be. Such decisions resourcefully bend the rules, reflecting both a highly original use of space and a logical and knowledgeable use of the canon.

As per the classic approach of practitioners of the neo-Russian style in church architecture, Stelletsky's murals at Saint-Serge were shaped through a mixture of

56 For other discussions of seraphim in church painting, see Chapter 2, p. 49 and Chapter 3, p. 76.

57 For a northern wooden church with such designs, see, for example, the early eighteenth-century Chapel of Archangel Michael in Kizhi, Karelia.

58 See, for example, the mid-sixteenth-century Virgin of the Sign icon in the State Historical Museum in Moscow. Alfredo Tradigo, Icons and Saints of the Eastern Orthodox Church, trans. by Stephen Sartarelli (Los Angeles, CA: J. P. Getty Museum, 2006), p. 173.

59 Ibid.

60 Several pages in one of Stelletsky's sketchbooks sold at Christie's are devoted to drawing seraphim, especially their wings, suggesting they might have proved difficult to execute. Christie's London (auction catalogue, 24 November 2014), lot 7. 
national and non-Russian medieval and contemporary sources. While some of his contemporaries referred to the church as a perfect "copy" of an Old Russian church, Stelletsky's general approach could not be further from imitation. ${ }^{61} \mathrm{He}$ went beyond the canon of the Orthodox Church both in his amalgamation and reinterpretation of various influences and the way in which he creatively filled the space of the church. Indeed the building's unsuitability as a traditional Orthodox church necessitated compromise, but Stelletsky still failed to paint the space wholly in a way that was classically Orthodox, notably avoiding figurative scenes that normally occupy church walls and ceilings. The colour and interplay of his ornamental motifs, as well as their overall dominance, even found a counterpart in the work of modernist artists such as Matisse, suggesting that Stelletsky's work was not altogether rooted in the past, but, at least in this case, engaged with aesthetic approaches beyond Russia's borders. This fusion of modern and medieval, aesthetic and spiritual, and tradition and innovation in the wall paintings at Saint-Serge made Stelletsky an important contributor to the neo-Russian style in church architecture.

61 See Iulia Reitlinger, quoted in Kotkavaara, Progeny, 259. 